\title{
CULTURAL VALUES ABOUT GENDER INEQUALITIES AND THEIR IMPLICATIONS FOR WOMEN'S HEALTH IN RURAL PUNJAB, PAKISTAN
}

\author{
Saira Siddiqui \\ Assistant Professor, Department of Sociology, \\ Government College University, Faisalabad, Pakistan \\ Nabeela Farah \\ Assistant Professor (visiting), Department of Sociology, \\ Government College University, Faisalabad, Pakistan \\ donia.nabeela@yahoo.com \\ Nazia Malik \\ Assistant Professor, Department of Sociology, \\ Government College University, Faisalabad, Pakistan \\ naziamalik@gcuf.edu.pk
}

\begin{abstract}
The cultural values about gender inequalities and their influence on women's health is the subject of this paper. The aim is to know the association of cultural values, their background regarding socioeconomic characteristics and beliefs about gender inequalities and the health of women. Also, policy measures with a view to the findings are considered. For this, quantitative and qualitative data was collected from the rural areas of Faisalabad and Multan Districts situated in Punjab, Pakistan. For quantitative study, a sample of 500 rural women was selected, for interviews and for qualitative study, 8 FGDs were conducted with the rural women belonging to different socio-economic backgrounds. Qualitative information was analyzed through content analysis techniques and SPSS was used to analyze quantitative data. The results showed that gender inequality was positively related with the mental and physical health of women. The recommendations are that the government should monitor all the tiers of the social structure to diagnose the limitations so that the programs to enhance equalities are promoted.
\end{abstract}

Key Words: Gender Inequalities, Cultural Values, Health

\section{INTRODUCTION}

Pakistan is a diverse country having four provinces, which further divide people on the basis of cultural values, norms and beliefs along with socio-economic patterns. Also, people of all the provinces practice various tribal and customary traditions associated with the specific province. These cultural values and traditions are important in their own way but their negative implication in a society is responsible for the evolution of different factors in the country and one of the fine example is gender equality that has affected the women not only in terms of their peaceful survival but also in terms of their basic right of health (Marlen, 2019). Gender equality in health implies that everyone has the privilege to spend healthful lives, promote health advancement, and profit from its' development. There is a need for more miscellaneous, comprehensive management in directing essentials for accomplishing the plans and projects for health promotion, justice, and fairness of job prospects for all (Global Health, 2019). Restraining opportunities on the basis of gender is not good for people's health, while realizing the causes of doing so should be the initial step in succeeding in the world. The emphasis here is on the harmful effects of gender inequality, along with the restrictive cultural standards and values for women and gender minorities (Digitale, 2019).

Pakistan is the second largest South Asian country with a population of 207.7 million. It is the fifth most populous country in the world where men with $51 \%$ have exceeded women with $49 \%$ of the total. Pakistan has international obligations to promote gender equality and women's human rights with the Universal Declaration of Human Rights, Beijing platform for action, and convention on the elimination of all forms of discriminations against women to promote sustainable development goals. The 2030 Agenda for Sustainable Development has aims for gender equality and how women should 
be made more independent and empowered and in order to do so, UN women in Pakistan is doing work for the enhancement of welfare of women. This paper is designed to highlight the cultural values about gender inequalities and their implications for women's health in rural Punjab, Pakistan. Major portion of the paper is assigned to the methodology for finding results by considering two cities of Punjab.

\section{Perception of Gender Equality}

Gender equality is defined as equal representation of women and men that can be measured (Canadian Association for the Advancement of Women \& Sport \& Physical Activity, 2013). The importance of gender equality is based on the need for the women to be more frequently and appropriately represented on different platforms in the developing countries as they have narrow access to social and economic resources. The hindrance in their presentation at major platforms is due to many factors and the causes of no equal right for women to access education or employment needs more attention. Various factors dealing with the education, resources, and human rights to enhance women's status will be seen and their impact studied. Health has been studied as a dependent factor and how it is influenced by various factors. The reality of women's vulnerability to subjugation and degradations in various parts of the world is felt in every society with their significant effects on women's health. The situation of income inequality was not encouraging during the period of 1990s. To this day, better conditions for women's health problems are on the agenda of gender equality, with new development plans to be devised, new projects for research and new acts were enacted for women protection regarding their rights. A complete life-cycle approach for the health of women come into focus to manage the issues that arose due to previous policies. It was pointed out that the gender gap between males and females in accordance with the socioeconomic factors led to discouraging results for development of a society (Beijing Declaration, 1995). The preamble of this study is to give a comprehensive analysis of gender disparities in Pakistan, which have become a serious challenge.

\section{Empowerment for Women}

Women empowerment in Pakistan is very important and a challenging issue due to its' roots in the local and religious backgrounds (Gafoor \& Muhammad, 2015). Women empowerment has emphasis on many aspects, as it foresees an approach to information, social and economic capitals for women and more self-sufficiency in financial and administrative matters especially in taking decisions (Kabeer, 2008). There is an irregular development of gender equality across country and that gives convincing opinions about both the reasons and outcomes of this progress (Moss, 2002; Norris, 2003). Decision making in the households along with resource allocation has remained focus of the literature of neo-classical economics. On the other hand, education for females is fruitful, e.g., in social and monetary benefits since they are counted as human capital asset (Khlat et al., 2000). A UN study shows that at the country level, there is no association between gender equity and economic inequality (World Bank, 2000). There is an increase because of the reason of women being breadwinners and having higher incomes in many situations (Karoly \& Burtless, 1995). Exchange of things and materials between two genders in the households cause an effect on decision-making, well-being and health (Dollar \& Gatti. 1999).

\section{THEORETICAL FRAMEWORK}

For this investigation, a theoretical framework was formed from a comprehensive model of the factors affecting women's health presented by Moss in her work "Gender Equity and Socioeconomic Inequality: A Framework for the Patterning of Women's Health", in which she explicates how socioeconomic and gender inequality determinants affect women's health with a number of independent variables. The framework uses the background of historical, geographical, legal, and political models giving details of ways of men and women leading their lives with certain cultural variables, where norms seem to affect their behavior (Moss, 2002).

In Pakistan, in several situations, long-established values in the families become too inflexible. There is prevailing inequity between genders as far as the marriages are concerned with a connection to economics of inequality (Majid, 2011). The powerful have the dominance and they exercise their authority in various aspects of life of people e.g., in their lives, work and social relationships. Gender inequality harms the females' physical and mental health throughout the world. And despite the 
comparative advantageous situation for the males as they have more access to resources and services, it affects them too. To lessen the health inequities, action needs to be taken to improve the conditions where women can get their rights to health (Grown et al., 2005).

\section{METHODOLOGY}

In the present research, triangulation method was used to collect empirical data from the rural women of the province of Punjab, Pakistan. The study was conducted in the rural areas of two major cities, Faisalabad, and Multan, in the Province of Punjab, Pakistan. Punjab is called the land of five rivers named Sutlej, Bias, Chenab, Ravi and Jhelum `as they flow through the plains of the province of Punjab and meet at a point called Punned. From there, they run and drop into Indus River at Kot Mithan (Chupra, 1977). Faisalabad is situated in Punjab and it is the third largest city of the province among the most populated cities of the country. The present population of this city is approximately 5,429,547. Multan city is a historical place of Pakistan and the capital of Multan District. It is situated in the south of Punjab. Being the 6th biggest city of the country, Multan is situated on the east side of river Chenab and is at about $966 \mathrm{~km}$ from Karachi (City District Government Multan, 2014). For quantitative data, personal questions and conversations were done through a well-structured questionnaire by the researcher herself, for the qualitative information, focus group discussions (FGDs) were carried in the same way. In both cases, the respondents were the rural women of age 18 and above. Historically, Pakistan has a tough male-controlled social structure and a large number of women are illiterate, who are expected to attend to their households and live their lives in a joint family system. Though the country has shown some progress in social and economic development, but the picture of gender equality is not so bright. Regarding gender disparities, based on the criteria of economy, education, health and politics, Pakistan is placed at 148 out of 149 countries, according to Global Gender Gap ranking (World Economic Forum, 2019). The Global Gender Gap Index gives the findings of nationwide surveys on gaps between the two genders on health-based standards regarding economic, political, and education situations and give country ranking to see a comparison in different regions of the world over a period of time (Hausmann et al., 2010).

For qualitative analysis, Focus Group Discussion (FGD) technique was used to collect information about the cultural values of the female respondents belonging to the rural areas of Multan and Faisalabad districts regarding gender inequality and their effect on the mental and physical health of the women. All the female participants of the FGDs belonged to different socioeconomic backgrounds and their age group was from 18 years and above. Some of them were illiterate and some were literate with different socio-cultural values system of their households and had different point of view and experiences. The total of 8 focus group discussions was conducted in the rural areas of Multan and Faisalabad. Two FGDs were conducted with the female teachers of girls' high school of the rural areas of Multan and Faisalabad, with special permission of their headmistresses. In addition to this, remaining six FGDs were conducted by using special reference with the rural women from different socio-economic background of Multan and Faisalabad. Different tools including tape recorders and pictures to introduce topics of discussion was used. Focus group sessions were recorded by both methods, i.e., by using tape recorder and by written notes taken by the researcher. The deductive process (from general to specific) for communication between the member and the researcher was set up to create an environment for more focused questions. The moderator began the discussion. The following question was afterwards asked: What is your view point about gender inequality in our society? In this research data collected from the 8 Focus Group Discussions was analyzed by using content analysis technique. Content denotes what is contained and content analysis is the analysis of what is contained in a message. The universe of this research study was comprised of all the adult women from the union councils of the two cities, Faisalabad and Multan. Purposive sampling technique was used for the present study and the multi-stage random sampling technique followed. The required size of the sample was calculated by using the Fitz Gibbon table. The present study was done in randomly selected two districts (Faisalabad and Multan) out of 36 districts of Punjab. One tehsil from each district containing rural population was selected by applying purposive sampling technique because the purpose was to collect information about inequalities from the rural women. Faisalabad district consists of six tehsils, out of which one tehsil Faisalabad Sadar was selected at next, two union councils were selected from Faisalabad Sadar tehsil out of 176 union councils by using simple random sampling technique. At second stage, each union council consists of 
three villages from which the sample of 250 women (18 years and above) were drawn by using the proportionate random sampling technique. Same sampling technique was applied to get sample of 250 respondents from the Multan. Multan district has four tehsils, out of which one was selected by using purposive sampling technique. One Tehsil naming Multan Sadar was selected because it consists of rural population. Next two Union Councils were selected from Multan Sadar tehsil out of 11 union councils by using simple random sampling technique. At third stage, each union council consists of four villages from which the three villages were randomly selected. At fourth stage, sample of 250 women (18 years and above) was drawn by using the proportionate random sampling technique from the three selected villages of district Multan because the population size was not equal. Overall 12 villages were selected from the selected Tehsils of the Faisalabad and Multan districts. From each tehsil 250 respondents were selected and interviewed, after using proportionate random sampling. Through a constructed questionnaire, data were collected from 500 women. Attitude and contingency questions were asked to know about the cultural values of the rural women about gender disparities. The quantitative and qualitative data was analyzed subsequently using statistical techniques. Keeping the respondents' information confidential, guidelines to keep the respondent's privacy was a big concern and its' secrecy was maintained. In Pakistan, gender inequality is a sensitive issue and research on it is handled with special care. In general, the study strictly followed the ethical and safety recommendations while collecting data from the female respondents.

\section{RESULTS}

The qualitative analysis results are given in different themes:

\section{Theme One: Community knowledge, awareness, and attitude towards gender inequality}

Most of the participants belonged to a joint family system. Four were divorced, three were widowed and some were single and living with their parents. The women, who were educated, had better knowledge about their rights and control over their resources, whereas the uneducated women were mostly not in favor of co-education and also opinioned that females should not ask about their right to property because it could create disputes within their families.

A joint family system was believed to be a major reason of gender inequalities as the in laws, at times, creates difficulties and misunderstanding among husband and wife. All the teachers were in favor of women property rights as that made their position stable in the society. One teacher thought that when a mother-in-law grows older, she loses control over the resources of her household and then most of the resources come in the hands of her daughter-in-law. She said that the men who physically abused women were cruel so she believed that females should have a right for mate selection and the parents should consult them in the mate selection process. Majority of the illiterate women were not in a favor of the right for their mate selection.

\section{Theme Two: Women's experience of gender inequalities in their households}

Women from different socio-economic backgrounds were having different experiences regarding inequalities. A teacher of 35 years of age was facing verbal abuse by her husband and said that this society was for men and it is very difficult to overcome gender inequalities. It is also very important for the mental and physical health of the women to be given freedom, education, and the property rights. Four teachers out of fourteen did not have the permission to spend and utilize their own salaries. One teacher said that she could not wear a dress according to her own choice and she is facing health issues like depression and blood pressure. She believed in freedom of women, so that she could make her own decisions about her life. She said that before marriage, her mental and physical health was much better as compared to her marital life where in-laws rough behavior made her suffer. Most of the literate females were in favor of education and especially education for the girls. The women were asked questions about their experiences of violence by their family members. Illiterate women, who were facing different types of violent behavior, were high in number as compared to the literate women.

\section{Theme Three: Cultural values of respondents about gender inequality}

Questions were asked to the respondents regarding their perspectives and beliefs about the role of women in society. Responses to these questions were complex, contradictory, and multi-layered. Most of the respondents said that they were willing to give "freedom" to their women but with certain 
restrictions. As in other developing countries, topics like "women" empowerment", gender equality" and "reproductive freedom" are hot debated topics. Those women who were treated equally at their homes had good mental and physical health. On the other hand, literate women strongly favored the education for females. In a rural set-up, respondents from different socio-economic backgrounds were mostly against complete independence of females. They thought that women should be given freedom according to the cultural values and women should not be allowed to select her mate for herself, rather it is up to the parents to do it as they are experienced and have better knowledge. Literate women thought that freedom should be given according to the Islamic values and women should be asked about their choice before marriage. A woman of fifty-five years old, widowed, and illiterate with three male children and one female, was living in a joint family system with non-cooperative in laws, who treated her badly. She suffered from blood pressure and muscle weakness. She told that when her husband was alive, she was treated well and her health was very good too. However, she believed that women should not take property share and not be allowed to select her marriage partner or do a job.

\section{Theme Four: Effects of cultural values regarding inequalities and health}

One woman, age sixty years, was illiterate and lived in a nuclear family, had several health problems. She was not given proper medical care because her husband was violent and abused her physically, psychologically, and verbally. She cried for medical health facilities but was neglected. Rashida, another respondent, who had three kids and was literate, her husband was an electrician. She got married with the choice of her parents. Whenever her husband got angry, she got depressed. He was a dry-natured person and psychologically abused her and made her cry. He did not let her watch TV. She could not protest as in rural areas; it was against the cultural norms to do so. That is the reason why rural women keep silent and suffer from abuse for their whole life. A woman named Maryam had a good socio-economic background and was highly educated but was not doing any job. Her husband was a doctor by profession, and she told that before marriage, her health was very good but after marriage, she suffered from diabetes after the birth of her kids. After the birth of their first child, her husband was stressed out and thus started abusing her physically and psychologically. She suffered from severe depression and started weeping during the focus group discussion. She expressed that a husband's cooperation is a major factor behind the health of a woman, and she becomes vulnerable when her husband is non-cooperative and violent. One girl of 18 years of age, unmarried and with poor economic conditions told that her brother and father treated her well and she made her own decisions. She was mentally and physically fit and believed in women education, right of property share and freedom for work.

\section{Theme Five: Women's coping strategies against gender inequalities}

Most of the women said that they remained silent when their husbands and male members were angry, because silence is the best method to keep the anger down. A respondent said that when her husband got angry, she kept silent as her children were married and she did not want to disturb them. Also, answering back was not believed to be of any good in that area. The results corroborate with the model followed in this study and the variables used to prove their association with women's health. Qualitative data research findings provided the opportunity to explore particular issues relating to effect of gender inequality on the health of rural women and were strongly supported by discussions of the group participants. The discussions unearth the inequalities women faced in a rural community. The participants were concerned with the influence of traditional cultural values on women's health. It was concluded that qualitative research strengthens the quantitative data results that investigated certain problems in deeper detail. The results about the effect of gender inequality, equity and social justice on the health of rural women have been strongly reinforced by FGDs participants. The comprehensive inclination in discussions was to expose a rural group where women were facing different forms of inequality. It is a tough basis to make policies to alter the mind-set which promotes inequality, inequity and injustice in a society, especially in rural areas by engaging the community to promote equality, equity, and social justice. The participants were worried about the impact of traditional cultural values and gender discrimination on women's health. Gender discrimination was perceived as causing social exclusion as people became self-centered. 
The quantitative analysis part of the paper shows the classification and statistical analysis:

Socio-economic characteristics in the form of frequency distribution

\begin{tabular}{|l|l|l|}
\hline Education & Females & \% \\
\hline Illiterate & 257 & 51.40 \\
\hline Up to primary & 78 & 15.60 \\
\hline Up to secondary & 85 & 17.00 \\
\hline Up to college & 62 & 12.48 \\
\hline Up to university & 18 & 03.60 \\
\hline Total & 500 & 100.0 \\
\hline Employed & & \\
\hline Yes & 161 & 32.0 \\
\hline No & 339 & 67.80 \\
\hline Total & 500 & 100.0 \\
\hline Occupation n=161 & & \\
\hline Govt. service & 20 & 12.42 \\
\hline Agriculture & 59 & 36.64 \\
\hline Education & 31 & 19.26 \\
\hline Health - Medicine & 17 & 10.56 \\
\hline Others & 34 & 21.12 \\
\hline Total & 500 & 100.0 \\
\hline Income & & \\
\hline Up to Rs.15000 & 220 & 44.00 \\
\hline From 15001-25000 & 167 & 33.40 \\
\hline From 25001-above & 113 & 22.60 \\
\hline Total & 500 & 100.0 \\
\hline The frequency distribution & & \\
\hline
\end{tabular}

The frequency distribution of the respondents according to their health problems

\begin{tabular}{|l|l|l|}
\hline Those with health problems & Females & \% \\
\hline Yes & 231 & 46.20 \\
\hline No & 269 & 53.80 \\
\hline Total & 500 & 100.0 \\
\hline Had gone to a doctor or not & & \\
\hline Yes & 225 & 45.00 \\
\hline No & 275 & 55.00 \\
\hline Total & 500 & 100.0 \\
\hline Had permi
\end{tabular}

Had permission to see a male doctor

\begin{tabular}{|l|l|}
\hline Yes & 45 \\
\hline
\end{tabular}

\begin{tabular}{l|l} 
No & 49 \\
\hline
\end{tabular}

\begin{tabular}{l|l} 
Total & 500 \\
\hline
\end{tabular}

09.80

\begin{tabular}{|l|l|l|}
\hline Blood Pressure & 44 & 19.04 \\
\hline Sugar & 23 & 09.96 \\
\hline Hepatitis & 23 & 09.96 \\
\hline Tuberculosis & 11 & 04.76 \\
\hline Pneumonia & 25 & 10.82 \\
\hline Cancer & 11 & 04.76 \\
\hline Kidney problem & 10 & 04.33 \\
\hline Gyne problems & 26 & 11.26 \\
\hline Tonsils & 6 & 02.60 \\
\hline Muscular & 11 & 04.76 \\
\hline Migraine & 17 & 07.36 \\
\hline
\end{tabular}




\begin{tabular}{|l|l|l|}
\hline Heart trouble & 24 & 10.39 \\
\hline Total & 231 & 100.0 \\
\hline \multicolumn{2}{|l|}{ The frequency distribution of the respondents according to their mental health problems } \\
\hline Mental health problems & Females & $\mathbf{\%}$ \\
\hline Yes & 224 & 44.80 \\
\hline No & 276 & 55.20 \\
\hline Total & 500 & 100.0 \\
\hline \multicolumn{2}{|l|}{ Type of mental problems of mentally sick respondents n=224 } \\
\hline Depression & 86 & 38.89 \\
\hline Hallucinations & 48 & 21.43 \\
\hline Schizophrenia & 42 & 18.75 \\
\hline Epilepsy & 21 & 09.38 \\
\hline Hysteria & 27 & 12.05 \\
\hline Total & 224 & 100.0 \\
\hline Ever visit to doctor & \multicolumn{2}{|l|}{} \\
\hline Yes & 59 & 11.80 \\
\hline No & 129 & 25.80 \\
\hline -Mentally healthy & 276 & 55.20 \\
\hline Total & 500 & 100.0 \\
\hline
\end{tabular}

The illiteracy rate of the respondents was $51.4 \%$ and the literacy rate was $48.6 \%$. Women educated up to primary comprised of $15.6 \%$, up to secondary $17 \%$ and up to college and above $16.48 \%$; this showed a moderate level of literacy. The employment category showed women doing any job were $32.2 \%$, and those without a job were $67.8 \%$. The household income showed that $44 \%$ of women were from the families with a monthly family income of up to Rs.15000; $33.4 \%$ were from the category of Rs.15001-25000, and 22.6\% from Rs.25001 and above.

Health problems of women are the dependent variable of this study. The above table shows that $46.2 \%$ of the respondents suffered from health problems and $53.8 \%$ did not. The unhealthy women had a range of diseases, like blood pressure, migraine, kidney problems and heart trouble. The information shows $45 \%$ respondents consulted the doctor while 55\% respondents did not; whereas a large majority could visit a male doctor and only a small percentage could not. The highest percentage, i.e., $19.05 \%$ had blood pressure, and the second highest were gynecological problems with $11.26 \%$ and heart trouble with $10.13 \%$.

According to the above table, the mentally sick respondents constituted $44.8 \%$ of the sample. They suffered from depression, hallucinations, schizophrenia, epilepsy and hysteria. Very few, i.e., about $12 \%$ respondents had consulted a doctor. Some were just lazy enough to visit a doctor and some were simply not allowed to.

Relationship between gender inequality and physical health problems of the women was analyzed by using Chi-Square and Pearson Correlation methods

\begin{tabular}{|l|l|l|l|l|}
\hline Gender Inequality & & Sick Women & Healthy Women & Total \\
\hline Low & f \% & $09(4.7)$ & $181(95.3)$ & $190(100.0)$ \\
\hline Medium & f \% & $86(50.3)$ & $85(49.7)$ & $171(100.0)$ \\
\hline High & f \% & $136(97.8)$ & $03(2.2)$ & $139(100.0)$ \\
\hline Total & f \% & $231(46.2)$ & $269(53.8)$ & $500(100.0)$ \\
\hline
\end{tabular}

$\chi^{2}$ value $=281.709 *$ Sig. $=.000 \quad \alpha=.05$

Pearson's $\mathrm{R}=.751^{*} \mathrm{Sig}=.000$

Gamma $=.960 * \mathrm{Sig}=.000$

The above table indicates that health problems are strongly associated with gender inequality and are highly significant. The Chi-square value of 281.709 was significant with $\mathrm{p}<.05$; the Pearson correlation value was .751 and highly significant as shown above. A high percentage of women, i.e., $97.8 \%$ in the category of index variable gender inequality showed positive association with health 
problems. This means where gender inequality is high, the health problems will also be high, i.e., when there is higher equality, the health problems are also faced by less number of women. The findings of the above hypothesis are similar to report by (WHO, 2011) which found out that less care for women and non-availability of basic health facilities led to increase in the health risks for women. Gender disparities affected health problems and women were vulnerable to diseases and infections of HIV/AIDS, malaria and chronic obstructive pulmonary disease. The findings are in agreement with Moss' (2002) that inequality within the households becomes a factor in forming women's health and an outcome of a multifaceted interaction of organic and natural factors including chromosomal, demographic, socioeconomic, psychosocial and social factors. Gender inequity joined with socioeconomic disparity makes a strong explanatory structure for differences in women's health. Whereas, WHO (2010) reported that both the genders are treated in an unequal manner regarding health requirements and are taken care of differently. Women bear several types of inequalities in behaviors with them that can be called injustice towards them even in case of common health. Women's Health East (2014) reported that gender inequality is found in income, education and jobs that are helpful for people's health, along with conventional normative patterns and beliefs and their commonness in society. English et al., (2003) observed that the function of a family is care, affection, and happiness, whereas, violence brings damage, annoyance, fury, and hurt. Familial abuse is seen at all stages and all relationships; among parents and children, brothers and sisters, married people, and dating relationships.

Relationship between gender inequality and mental health problems

\begin{tabular}{|l|l|l|l|l|}
\hline Gender Inequality & & $\begin{array}{l}\text { Mentally Sick } \\
\text { Women }\end{array}$ & Healthy Women & Total \\
\hline Low & f $\%$ & $10(5.3)$ & $180(94.7)$ & $190(100.0)$ \\
\hline Medium & f $\%$ & $83(48.5)$ & $88(51.5)$ & $171(100.0)$ \\
\hline High & f $\%$ & $131(94.2)$ & $8(5.8)$ & $139(100.0)$ \\
\hline Total & f $\%$ & $224(44.8)$ & $276(55.2)$ & $500(100.0)$ \\
\hline $\begin{array}{l}\chi^{2} \text { value }=258.481 * \text { Sig. }=.000 \\
\text { Pearson's R }=.719 * \text { Sig }=.000 \\
\text { Gamma }=.937 * \mathrm{Sig}=.000\end{array}$
\end{tabular}

Above table presented an association between mental sickness with gender inequality. The Chi-square value of 258.481 is also highly significant with $\mathrm{p}=.000$, less than the alpha level of significance of 0.05 . The Pearson correlation value is .719 and highly significant. A percentage of 94.2 are seen in High category of gender inequality and health problems. The women respondents, who suffered from mental sickness believed that gender inequalities affected mental sickness. The findings above validated Ibrahim et al., (2012) study, which observed that gender inequalities were found at a local as well as at the country or international level, whether they were internal or exposed ones, and that they might include being aggressive, intimidating, dominating and intensely forceful to females all their lives. Such a kind of behavior starts from an early age and happened alongside, successively. They are transmitted and imparted through the family and other institutions of a social set-up. Also Dorothy et al., (2004) said that depression and physical health has a bidirectional association as one increased the other and vice versa.

\section{CONCLUSION}

It was concluded that qualitative data research findings provided the opportunity to explore particular issues relating to effects of gender inequality on the health of rural women and were strongly supported by group participants' discussions. It was concluded that qualitative data strengthened the quantitative research results and gave the chance to look into specific matters in details. Quantitative findings relating to effect of gender inequality on the health of rural women have been substantiated by FGD participants. The results of the quantitative analyses corroborate the findings of Moss (2002) whose model was followed and showed many variables interrelating with gender inequality and equity at the socioeconomic level and revealed the relationship of these variables with impact on 
women's health. Moss (2002) saw different factors affecting women's productive and reproductive roles, at home and at workplace both. This was due to the cultural values, normative patterns, and social sanctions in the environment women operated. It provided a foundation from which public policy could be built for future plans to change the traditional values that promote inequalities in society especially in rural areas by involving and motivating the community members. The participants were concerned with the influence of traditional cultural values on women's health. Gender inequalities were seen as contributing to social exclusion by making people selfish.

\section{RECOMMENDATIONS}

More studies on inequalities need to be conducted through qualitative research. The majority of women believed that education can improve the situation of women. One woman in her late forties with a university education stated that women should know their rights and must not tolerate abuse. Some women were of the view that doctors, especially the lady doctors should help the victims. The mothers have to treat their sons and daughters equally. A committee should be established to provide social, economic and emotional support to the women facing inequalities at a neighborhood level. Women should be given proper representation at all levels of government and be empowered through their effectual/efficient application and partaking at different levels of social and financial policies. Governmental organizations working for women's rights should look for such innovative approaches, especially in order to harness the power of the community's social capital and mobilize society's moral and religious norms to protect and support vulnerable women. Pertinent programs that can be fruitful should be initiated for females' education and employment opportunities should be created. Government should strongly support and commit itself to develop and better the conditions of women. Steps for rural women towards progress must be taken. Women should be facilitated to take part on equal conditions as men through education, guidance, child-care amenities. Government should generate resources of automobiles, water pumps and cooktops to lessen women's workloads and enable their involvement in different programs. Government should improve systems to allow women to set-up a steady mechanism to bring together possible prospective employers. Financial services should be made available, so that women would be able to save or capitalize their savings in new monetary undertakings to raise profits of their programs and the elements of achievements. Women should be encouraged to take part in leadership and membership of bodies that administer labor rights to the highest levels. Government must improve and advance rural ground-work set-ups, with special focus on water-management, markets and means of communication and travel. Authorities must build up social amenities in villages like health facilities to reduce and relieve the unpaid village women from undue burden.

\section{REFERENCES}

Beijing Declaration and Platform for Action, Convention for the Elimination of Discrimination against Women. (1995). Accessed from: http://www.un.org/womenwatch/daw/cedaw.

Canadian Association for the Advancement of Women and Sport and Physical Activity, N202 - 801 King Edward Avenue, Ottawa, ON, Canada, K1N 6N5. (2013). Accessed from: http://www.un.org/womenwatch/osagi/pdf/factsheet2.pdf

Chopra, G. L. (1977). The Punjab as a sovereign state. Al-Biruni Publisher.

City District Government Multan. (2014). Accessed from: https://en.wikipedia.org/wiki/Multan_District

Digitale, E. (2019). Gender inequality and rigid norms linked with poor health, global research shows, Stanford Medicine. Accessed from: https://scopeblog.stanford.edu/2019/05/31/genderinequality-and-rigid-norms-linked-with-poor-health-global-research-shows/

Dollar, D., \& Gatti, R. (1999). Gender inequality, income and growth: Are good times good for women? World Bank, Development Economics Research Group, Poverty Reduction and Management

Network. Retrievedfromhttps://www.researchgate.net/publication/238237787_Gender_Inequality_Inco me_and_Growth_Are_Good_Times_Good_for_Women/stats

Dorothy, D. D., John, S. L., Larry, M. M., Jing, S., \& Rowland, W. C. (2004). Arthritis and Heart Disease as Risk Factors for Major Depression. Medical Care, 42(6), 502-11. 
English, D. J., Marshall, D. B., \& Stewart, A. J. (2003). Effects of family violence on child behavior and health during early childhood. Journal of Family Violence, 18(1), 43-44.

Gafoor, A. A., \& Muhammd, A. I. (2015). Role of Microfinance in self-employment creation: A case study of Bahawalpur. Journal of Economic and Sustainable Development, 6(7), 38-44.

Global Health (2019). Towards gender equality in global health. Retrieved from: https://globalhealth5050.org/gender-and-global-health/

Grown, C., Gupta G. R., \& Pande, R. (2005). Taking action to improve women's health through gender equality and women's empowerment. Lancet, 365, 541-543.

Hausmann, R., Tyson, L. D., \& Zahidi, S. (2010). The Global gender gap report. Geneva.

Ibrahim, K., Jeffery, A., Iris, L., \& Lydia, O. (2012). Gender Inequality and Its Effects in Females Torture Survivors. Psychology, 3(4), 352-363.

Kabeer, N. (2008). Paid Work, Women's Empowerment and Gender Justice: Critical Pathways of Social Change.

Retrievedfrom:https://www.researchgate.net/publication/305278764_Paid_work_women's_e mpowerment_and_gender_justice_critical_pathways_to_social_change/stats\#fullTextFileCon tent

Karoly, L. A., \& Burtless, G. (1995). Demographic change, rising earnings inequality, and the distribution of personal well-being, 1959-1989. Demography, 32, 379-405.

Khlat, M., Sermetm C., \& Pape, A. L. (2000). Women's health in relation with their family and work roles: France in the early 1990s. Social Science and Medicine, 50, 1807-1825.

Majid. H. (2011). State of gender inequality. Dawn news. Retrieved from: https://www.dawn.com/news/599978/state-of-gender-inequality.

Rotter, T. M. (2019). Gender Inequality in Pakistan. Causes and Consequences from Feminist and Anthropological Perspectives (Doctoral Dissertation, University of Universitat Jaume).

Moss, N. E. (2002). Gender equity and socioeconomic inequality: A framework for patterning of women's health. Social Science and Medicine, 54(5), 649-661.

Norris, P., \& Inglehart, R. (2003). The Rising Tide: Gender equality and cultural change around the world. Cambridge University Press.

Women's Health East. (2014). Investing in equality and wellbeing for women, Gender equity for health outcomes. Retrieved from: http://whe.org.au/what-we-do/gender-equity-for-healthoutcomes/.

World Bank. (2000). Agriculture in South Asia: Pakistan's Priorities for Agriculture and Rural Development.

World Economic Forum. (2018). Pakistan on worst performers on gender equality. Dawn. Retrieved from: https://www.dawn.com/news/1452284.

World Health Organization. (2010). Mental health: strengthening our response. Retrieved from: http://www.who.int/mediacentre/factsheets/fs220/en/.

World Health Organization. (2011). Retrieved from, http://www.who.int/features/factfiles/women/en/. 